\title{
A Mid-Recession and Post- Recession Comparison of Chain-of-Custody Certification in the U.S. Value-Added Wood Product Manufacturing Sector
}

\section{Usporedba CoC certifikacije u sektoru proizvođača finalnih drvnih proizvoda u SAD-u tijekom recesije i u postrecesijskom razdoblju}

\author{
Original scientific paper • Izvorni znanstveni rad \\ Received-prispjelo: 20. 5. 2016. \\ Accepted-prihvaćeno: 15. 11. 2016. \\ UDK: $630 * 79$ \\ doi:10.5552/drind.2017.1628
}

\begin{abstract}
In this paper we examine changes in perceptions, attitudes, and participation in chain-of-custody $(\mathrm{CoC})$ certification in the U.S. value-added, or secondary wood products sector between the period of the Great Recession (2007) and post-recession (2014). Data were collected for two studies conducted in 2008 (for 2007 annual data) and 2015 (for 2014 annual data) using web-based surveys administered by various value-added wood product associations on behalf of the researchers. Results show that understanding of CoC certification, purchases of certified raw materials, and costs to sell certified products increased over this period. The primary reasons for getting involved in certification changed from market driven (growing markets, increasing sales, and expanding market share) to customer driven (customer request) suggesting that respondents were attempting to use certification to become more competitive during the recession when many companies in the U.S. went out of business and employment in the sector declined. Nearly $100 \%$ of respondents in both studies said that they planned on continuing sales of certified wood products.
\end{abstract}

Key words: chain-of-custody certification, value-added wood products, United States

SAŽETAK • U radu je opisano istraživanje promjena u percepciji, stajalištima i sudjelovanju u certifikaciji lanca sljedivosti (CoC) u sektoru proizvođača finalnih odnosno sekundarnih proizvoda od drva u SAD-u u razdoblju od velike recesije (2007.) do postrecesije (2014.). Podaci su prikupljeni iz dvaju istraživanja koja su provedena $u$ 2008. (godišnji podaci za 2007.) i 2015. (godišnji podaci za 2014.). Istraživanja su realizirana uz pomoć web-anketa što su ih za istraživače provele različite udruge proizvođača finalnih drvnih proizvoda. Rezultati pokazuju da

\footnotetext{
Author is director and Crosby Land \& Resources Endowed professor, Louisiana Forest Product Development Center, Louisiana State University Agricultural Center, Baton Rouge, Louisiana, United States, ${ }^{2}$ Authors are graduate research assistant, professor and professor, Department of Wood Processing and Industrial Engineering, Purdue University, West Lafayette, Indiana, United States.

Autor je ravnatelj i profesor Centra za razvoj šumskih proizvoda, Poljoprivredni centar Državnog sveučilišta u Louisiani, Baton Rouge, Louisiana, SAD. ${ }^{2}$ Autori su znanstveni asistent i profesori Zavoda za obradu drva i industrijsko inženjerstvo, Sveučilište Purdue, Zapadni Lafayette, Indiana.
} 
su se razumijevanje CoC certifikata, kupnja certificiranih sirovina te prodajna cijena certificiranih drvnih proizvoda u navedenom razdoblju povećali. Glavni su se razlozi za uključivanje proizvođača u certificiranje promijenili i nisu više potaknuti tržištem (rastućim tržištima, povećanjem prodaje i širenjem tržišnog udjela) već zahtjevima kupaca. To upućuje na zaključak da se ispitanici pokušavaju koristiti certifikatom kako bi postali konkurentniji u vrijeme recesije, kada su mnoge tvrtke u SAD-u obustavile poslovanje, a zapošljavanje se u sektoru smanjilo. Gotovo $100 \%$ ispitanika u obje studije izjasnilo se kako planiraju nastaviti prodaju certificiranih proizvoda od drva.

Ključne riječi: CoC certifikat, finalni drvni proizvodi, SAD

\section{INTRODUCTION} 1. UVOD

Concerns regarding tropical deforestation and the need for sustainably managed forest resources led to the emergence of forest certification programs in the early 1970s (Espinoza et al., 2013, 2012; Marx and Cuypers, 2010; Vlosky et al., 2009). Since that time, several factors such as government regulations, environmental activism, corporate social responsibility, and "green" investors, have influenced the growth of forest certification around the world (Cashore et al., 2004; Maletz and Tysiachniouk, 2009).

Forest certification primarily aims to confirm that management of a specific forest area conforms to standards set by third party organizations. The major programs used by U.S. forest landowners and wood products manufacturers are Forest Stewardship Council (FSC), Sustainable Forestry Initiative (SFI) and Program for the Endorsement of Forest Certification (PEFC), and to a lesser degree, Scientific Certification Systems (SCS) (FSC, 2016; PEFC, 2014; SFI, 2015b; Vlosky et al., 2003). In addition to third-party certification, the existence of first and second party certifications are acknowledged and often classified under selfregulation title (Marx and Cuypers, 2010).

Forest certification standards can be summarized under the three main categories, namely, performance based standards, system-based standards, and the ones that are a combination of the first two types. For instance, FSC is a performance based system in which forest resource is being compared to pre-set performance indicators, while within the scope of a system-based standard, the primary focus is on the adoption of predefined procedures. On the other hand, PEFC and SFI schemes employ combined certification standards and expect applicants to conform to the requirements of them (Espinoza et al., 2012). Dovetail Partners has released a report addressing various aspects and differences of FSC and SFI programs. The authors concluded that the differences between the standards of these two certification schemes are present and varying from region to region (Fernholz et al., 2015; Fernholz et al, 2010). However, the distinction ratio has been degrading to a lesser degree in recent years, especially after last revisions of both FSC and SFI standards occurred in 2012 and 2010, respectively (Fernholz et al., 2015; FSC, 2016; SFI, 2015b) . It is also emphasized that the choice between FSC and SFI program totally depends on casespecific considerations involving economic, social and environmental factors (Fernholz et al., 2015; Fernholz et al., 2012; Fernholz et al., 2010). Sustainable forest management (SFM) criteria of PEFC are based on internationally recognized standards and indicators developed as a result of joint effort of government agencies all over the world. Thus, this organization functions like an umbrella that incorporates diversity of certification systems that pledge to meet its rigorous criteria under the same roof (Bowers et al., 2014; Espinoza et al., 2012; Moore et al., 2012; PEFC, 2015).

In addition to the forest management component of certification, most certification schemes also provide chain-of-custody certification $(\mathrm{CoC})$. The main purpose of $\mathrm{CoC}$ is to ensure that certified product is being processed in accordance with the guidelines and rules of specific certification program throughout the supply chain, from forests to the final consumer, by tracking and monitoring the material as it is formed into a pre-decided end item such as upholstered furniture, kitchen cabinets or wood flooring materials (Berg and Lovaglio, 2012; Espinoza et al., 2012; Vlosky et al., 2009).

Annual progress reports of FSC and PEFC show the trends of Chain of Custody ( $\mathrm{CoC})$ certificates issued by these certification programs. The most recent reports of FSC indicates that 5,257 CoC certificates have been issued to companies in U.S. and Canada as of end of 2015, a $5 \%$ increase from the previous year (FSC, 2016). In addition, 439 CoCs, 260 in U.S. and 79 in Canada, have been issued by SFI by the end of 2014 (SFI, 2015a, 2015b).

This paper focuses on certification in the context of downstream members of the wood products supply chain that includes value-added or secondary products. Secondary products use primary products as input for re-manufacturing and include furniture, cabinetry, doors, flooring and millwork, whereas primary products are produced directly from logs such as lumber and plywood. The largest demand sector for both primary and secondary wood products is new home construction, also termed housing starts. Housing can be single family or multifamily, including apartments, condominiums and townhomes. The secondary wood product sector follows because new homes include floors, doors and millwork. Also, when people move into new homes, they typically purchase new furniture.

According to Federal Reserve Economic Data (FRED), seasonally adjusted annual housing starts in the U.S. reached a peak of 2.2 million in the 2005-2006 period. Accordingly, the wood products industry was extremely healthy with record production and employment. However, the "Great Recession" of 2007-2008 marked two consecutive years of significant reductions in housing starts, severely harming the U.S. forest 


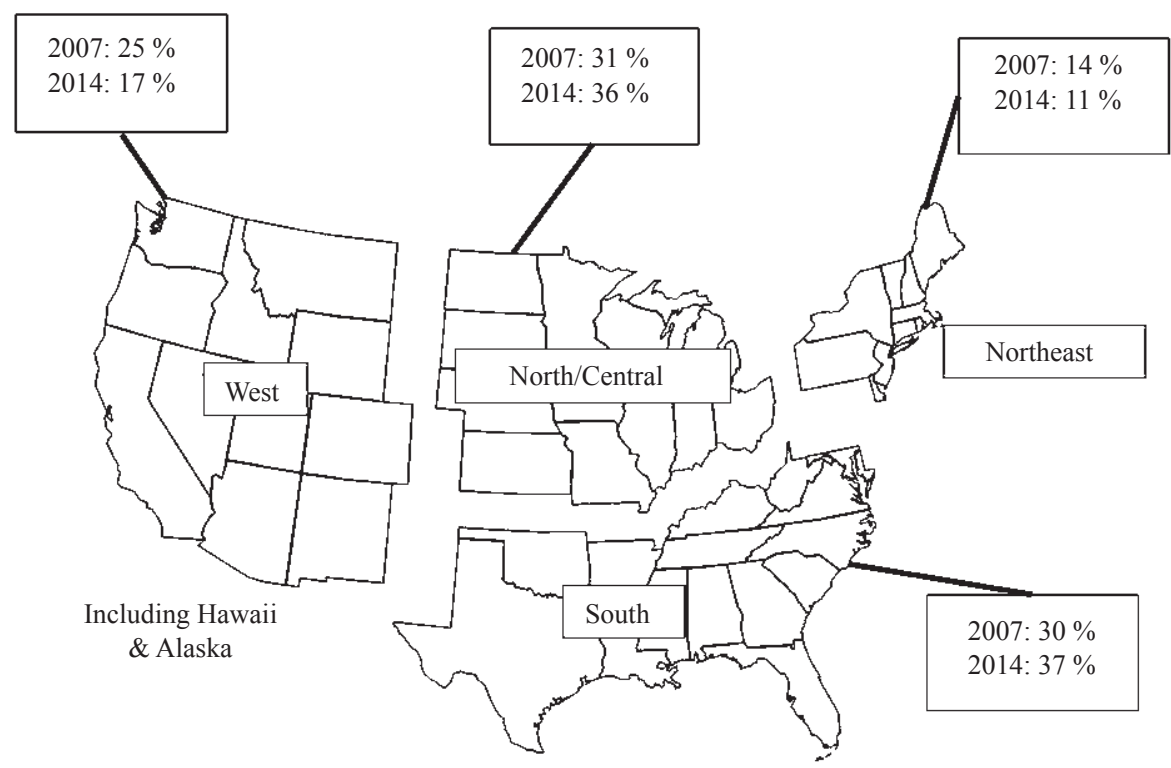

Figure 1 Respondent corporate headquarter locations (percent of respondents) $(2007: n=464 ; 2014: n=251)$ Slika 1. Lokacije korporacijskih sjedišta ispitanika (postotak ispitanika) $(2007 .: n=464 ; 2014 .: n=251)$

products sector, both primary and secondary. Housing starts have never fully recovered. As such, we wanted to see if there may be any underlying effects of the recession on certification adoption and structure for the value-added, secondary wood products sector.

\section{MATERIALS AND METHODS}

\section{MATERIJALI I METODE}

In 2008 and 2015, we conducted studies (for annual data from the previous years, 2007 and 2014) to identify value-added wood industry perspectives and participation in certification and to see what has changed in the industry since the "Great Recession". The data are from the previous years from when the studies were conducted, i.e., 2007 and 2014. We used SurveyMonkey ${ }^{\circledR}$ a web-based survey program. The data are presented for the previous years (the years that respondents were asked to report on). The questionnaires were sent by partner associations to their members on our behalf ${ }^{1}$. These associations required anonymity for their members and as such, controlled the dissemination of the surveys. Hence, only one "mailing" was sent for each time period. The associations did include a cover letter encouraging the recipients to participate in the studies.

\section{RESULTS AND DISCUSSION}

3. REZULTATI I RASPRAVA

\subsection{Respondent demographics}

\subsection{Demografska slika ispitanika}

There were 464 and 251 respondents in 2007 and 2014, respectively. Due to the methods used, we could

\footnotetext{
${ }^{1}$ Association for Retail Environments (A.R.E.); Architectural Woodwork Institute (AWI); Business and Institutional Furniture Manufacturer Association (BIFMA); Kitchen Cabinet Manufacturers Association (KCMA); and the National Hardwood Flooring Association (NHFA).
}

not determine response rates for the studies. In addition, although the same sector was surveyed, respondent companies, key respondents and response rates were different for each period. However, frequencies of respondent geographic locations (Figure 1) and frequencies of raw materials used by respondents (Figure 2 ) in the two time periods are not statistically different. For both years, the majority of respondents were in the South and North/Central regions of the U.S. and composite panels were the most used raw material followed by North American hardwood lumber and North American plywood and veneer. The pattern of respondent company size shifted between 2007 and 2014 from smaller companies. Sixty-one percent and $41 \%$ of respondent companies had 50 or less employees in 2007 and 2014 , respectively. In $2007,27 \%$ of respondents had more than 100 employees and increasing in 2014 to $46 \%$ of respondents.

\subsection{Understanding and knowledge - certification concepts and certifiers}

3.2. Razumijevanje i znanje - koncepti certificiranja i certifikatori

We first asked respondents to rate their level of understanding of forest management and Chain-ofCustody certification using a 5-point Likert scale anchored on $1=$ Do not Understand at All; $3=$ Somewhat Understand; $5=$ Completely Understand. Using 2-tailed t-tests, we found that with regard to Forest Management certification, the overall level of understanding was high and there was no statistical difference in mean responses at $\alpha=0.05$ level of significance (4.1 and 4.2 for 2007 and 2014, respectively). The level of understanding of Chain-of-Custody certification did see a statistically significant increase at $\alpha=$ 0.01 from 3.9 in 2007 to 4.2 in 2014. This is the type of certification that value-added wood products manufacturers are involved in.

We then asked about respondent understanding of the three major certification programs' objectives, Forest Stewardship Council (FSC), Sustainable For- 
Vlosky, Tasdemir, Gazo, Cassens: A Mid-Recession and Post-Recession Comparison... ......

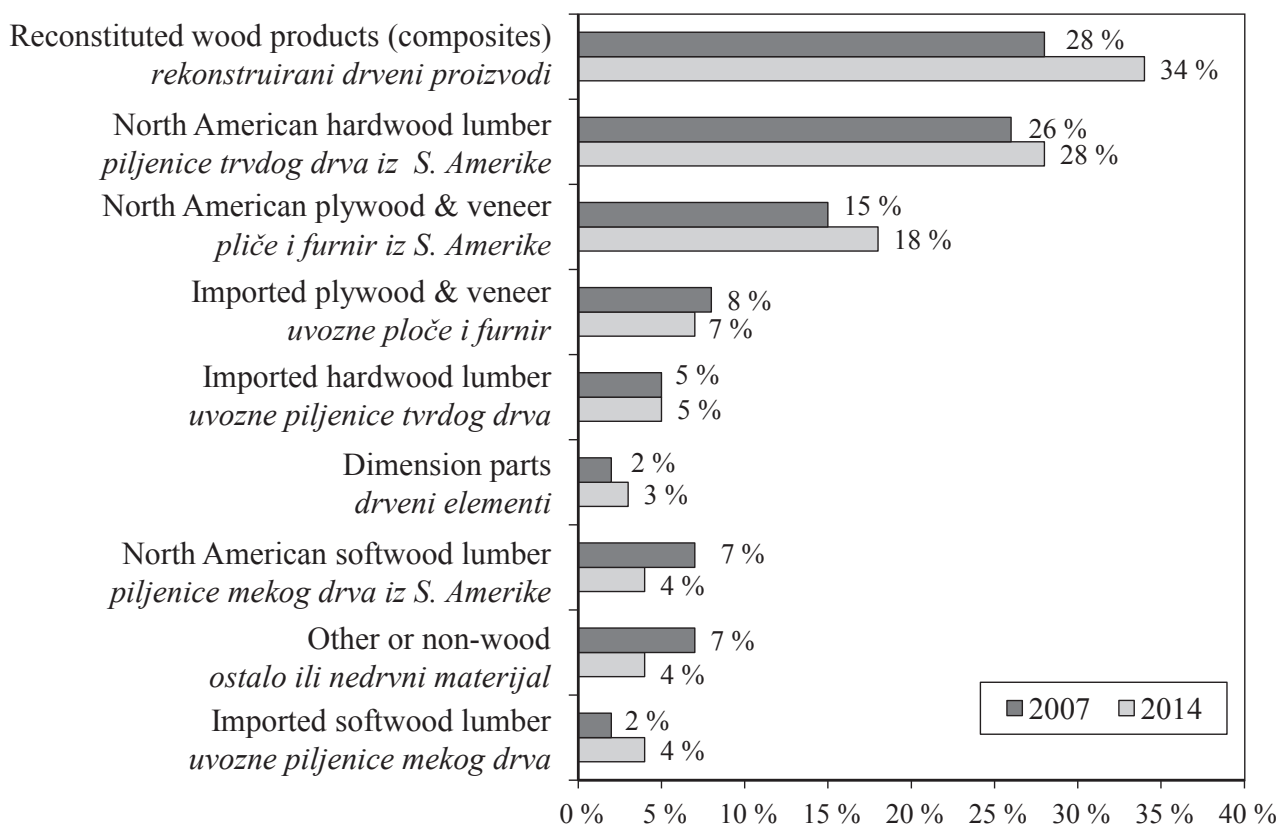

Figure 2 Raw materials used by respondents (percent of respondents) (multiple responses possible) (2007: $n=464 ; 2014: n=251)$ Slika 2. Sirovina kojom se koriste ispitanici (postotak ispitanika; mogući su višestruki odgovori) (2007.: $n=464 ; 2014 .: n=251$ )

estry Initiative (SFI), and Program for the Endorsement of Certification (PEFC). From 2007 to 2014, respondent mean understanding of PEFC and SFI declined significantly at $\alpha=0.01$ (PEFC: 3.3 to 2.5 ; SFI: 3.4 to 2.9 ). For FSC, the average level of understanding increased significantly at $\alpha=0.01$ from 3.7 to 4.2 .

We also wanted to know what all respondents thought about their certification business practices and perceptions in general. Using Likert Scale anchored on $1=$ Strongly Disagree; $3=$ Somewhat Agree; $5=$ Strongly Agree, the level of agreement from respondents that seek out suppliers of certified wood raw materials has increased marginally from 2007 to 2014 (Figure 3). The level of agreement regarding the belief that their customers would pay a premium for certified wood products decreased marginally (2.6 to 2.5 ) and the level of agreement that they would pay a premium for certified wood raw materials remained flat at 2.5. The final question posed to all respondents was whether they have actually purchased certified raw materials over the previous year. In this case, the average levels of agreement were higher than the midpoint and the increase in the level of agreement was significant at $\alpha$ $=0.01$, increasing from 3.3 in 2007 to 4.0 in 2014 .

\subsection{Respondents with certification}

3.3. Ispitanici s certifikatom

The percent of respondents that sold certified wood products increased from $12 \%$ in $2007(n=$ $11 / 152$ that responded) to $83 \%$ in $2014(n=76 / 92$ that

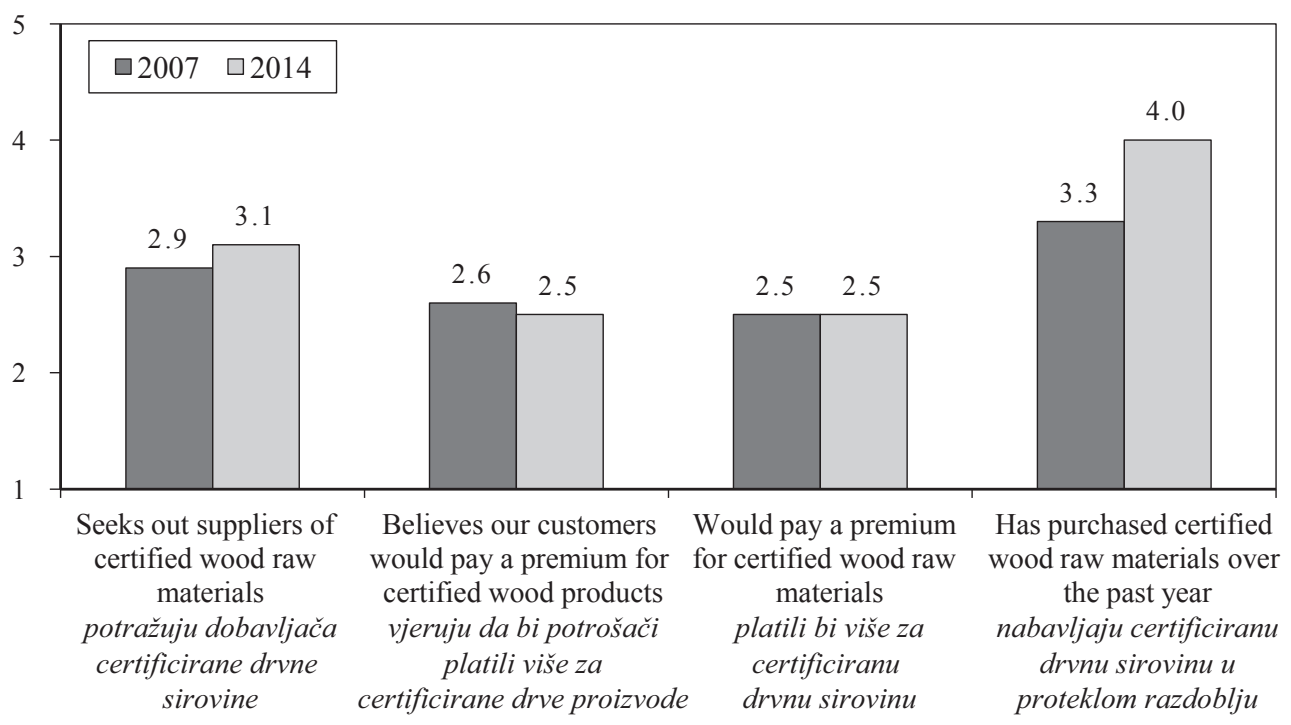

Figure 3 General certification concepts (2007: $n=454 ; 2014: n=153)$ (Scale: 1 = Do Not Agree at all; 3 = Somewhat Agree; $5=$ Completely Agree)

Slika 3. Opći koncepti certificiranja $(2007 .: n=454 ; 2014 .: n=153)$ (ljestvica: 1 - uopće se ne slažem; 3 - uglavnom se slažem; 5 - potpuno se slažem) 
Table 1 Certification plans for the future (percent of respondents without certification)

Tablica 1. Budući planovi certificiranja (postotak ispitanika bez certifikata)

\begin{tabular}{|c|c|c|}
\hline & $\begin{array}{c}2007 \\
(n=269)\end{array}$ & $\begin{array}{c}\mathbf{2 0 1 4} \\
(n=63)\end{array}$ \\
\hline $\begin{array}{l}\text { Obtain chain-of-custody certification within } 1 \text { year? } \\
\text { Planirate li dobiti CoC certifikat unutar jedne godine? }\end{array}$ & $11 \%$ & $10 \%$ \\
\hline $\begin{array}{l}\text { Obtain chain-of-custody certification within } 2 \text { years? } \\
\text { Planirate li dobiti CoC certifikat unutar dvije godine? }\end{array}$ & $10 \%$ & $2 \%$ \\
\hline $\begin{array}{l}\text { Monitor developments and obtain chain-of-custody certification if needed? } \\
\text { Pratite li razvoj i planirate li dobiti CoC certifikat ako vam bude potreban? }\end{array}$ & $58 \%$ & $60 \%$ \\
\hline Ignore chain-of-custody certification? / Ignorirate li CoC certifikat? & $20 \%$ & $29 \%$ \\
\hline
\end{tabular}

responded), a significant increase at $\alpha=0.01$ using Pearson Chi-Square test $\left(\chi^{2}=0.000\right)$. As certification becomes an increasingly important part of the business structures for respondents, their level of understanding of $\mathrm{CoC}$ certification processes increased commensurately. Using a 5-point Likert scale of understanding (1 = Poor, 2 = Fair, 3 = Good, 4 = Very Good, $5=$ Excellent), in 2007, $65 \%$ of respondents said they had a Very Good or Excellent understanding of certification. In $2014,80 \%$ of respondents had this level of understanding. This difference was significant at $\alpha=0.01$ ( $p$ $=0.000)$ using a 2-tailed t-test.

For the respondents that indicated that they did not sell certified wood products at the time that the surveys were conducted, we asked what their plans were for the future (Table 1). The vast majority of respondents for both studies said they were going to monitor the situation and obtain Chain-of-Custody $(\mathrm{CoC})$ certification if necessary (2007: $58 \%$; 2014: $60 \%$ ). The percent of respondents that said they were planning on getting CoC within one year was similar for both 2007 and 2014 as was the percent of respondents that said they were simply going to ignore certification completely. The response with the biggest disparity was for respondents that were going to obtain $\mathrm{CoC}$ within two years, decreasing from $10 \%$ of respondents in 2007 to $2 \%$ in 2014.

Why did respondents get involved in certification? Figure 4 shows that responding to customer requests became the primary reason over time, a shift from attempts to build markets and sales. All of the other possible reasons declined from 2007 to 2014. The authors suggest that this is due to the "Great Recession" that prompted respondents to try most anything to be more competitive during these turbulent economic times. These pressures appear to have waned in the intervening years since the recession.

The percent of respondents with Chain-of-Custody certification jumped almost $600 \%$ from 2007 to 2014 with $12 \%$ and $83 \%$ of respondents stating that this was the case, respectively. This was a significant increase at $\alpha=0.01$ using Pearson Chi-Square test $\left(\chi^{2}=\right.$ 0.000). For both years, Forest Stewardship Council (FSC) certification was most prevalent for $83 \%$ and 85 $\%$ of respondents in 2007 and 2014, respectively (Figure 5). Other certification programs used by respondents were Sustainable Forestry Initiative (SFI), Program for the Endorsement of Forest Certification

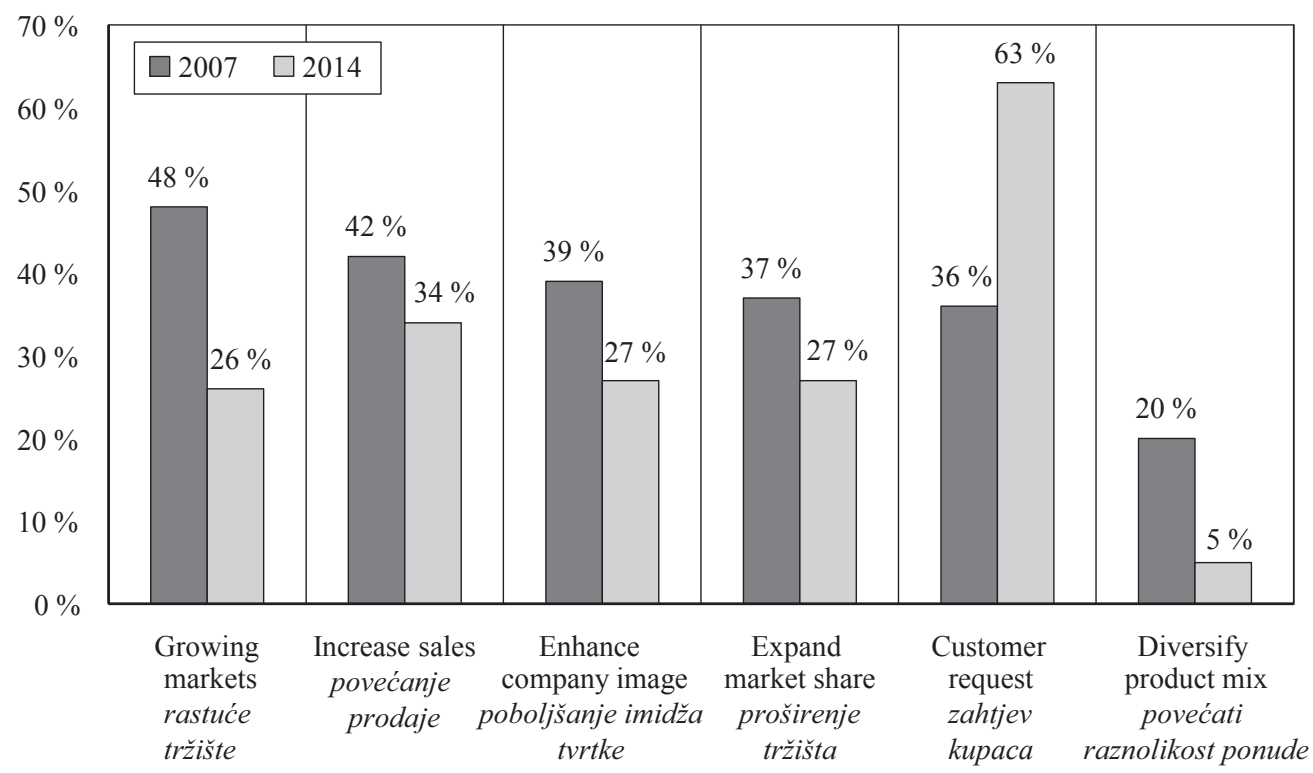

Figure 4 Why respondents became involved in certification (percent of respondents) (multiple responses possible) (2007: $n=$ 193; 2014: $n=99$ )

Slika 4. Razlozi uključivanja ispitanika u certificiranje (postotak ispitanika; mogući su višestruki odgovori) (2007.: $n=193$; 2014.: $n=99$ ) 
2007

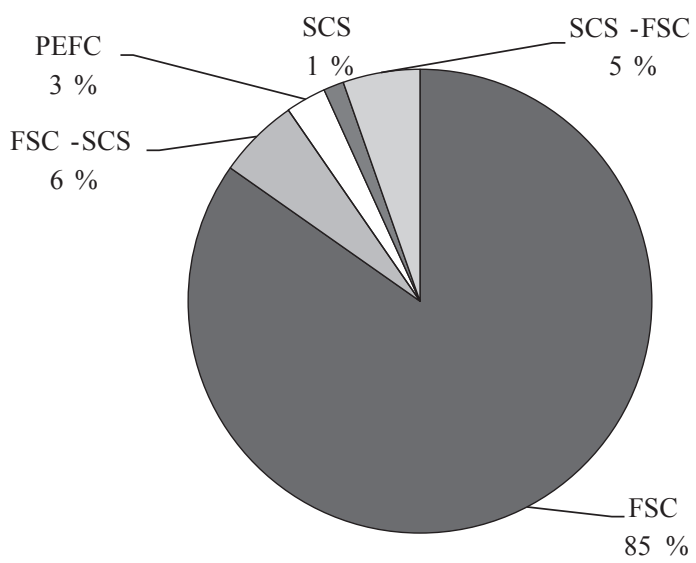

2014

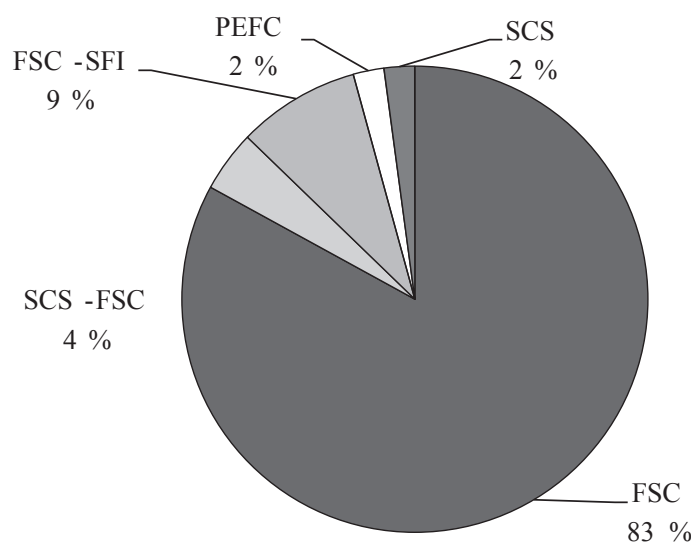

Figure 5 Chain-of-custody certification program used by respondents (percent of respondents) $(2007: n=193 ; 2014: n=99)$ Slika 5. Programi CoC certificiranja kojima se koriste ispitanici (postotak ispitanika) $(2007 .: n=193 ; 2014 .: n=99)$

(PEFC), Scientific Certification Systems (SCS), or combinations of these programs.

\subsection{Certified raw material purchases}

3.4. Nabava certificirane sirovine

On the wood raw material supply side, on average, the percent of wood products purchase costs attributed to certified products increased from $20 \%$ in 2007 to $33 \%$ in 2014, a statistically significant difference at $\alpha=0.05(\mathrm{p}=0.012)$ using a 2 -tailed t-test. The percent of respondents requesting that their wood raw material suppliers become certified increased marginally from $50 \%$ to $51 \%$ in 2007 to 2014 . As shown earlier, customer demands for certified wood products are increasing, so it is no surprise that respondents are pressuring their suppliers to provide certified raw materials. With multiple responses possible, over the two time periods, respondent sourcing of certified raw material internationally (27\% to $35 \%$ of respondents) and direct purchases from domestic suppliers (61\% to $73 \%$ of respondents) increased with a decline sourced from U.S. brokers/wholesalers (50 \% to $46 \%$ ). In addition, in $2007,74 \%$ of respondents said they paid a

Table 2 The top 5 problems faced when purchasing certified wood raw materials (ranked: $1=$ worst problem to $5=$ least worst problem) (2007: $n=193 ; 2014: n=99)$

Tablica 2. Najčešćih pet problema s kojima se ispitanici suočavaju pri nabavi certificirane drvne sirovine (rang: 1 - najveći problem, 5 - najmanji problem) (2007.: $n=193$; 2014.: $n=99$ )

\begin{tabular}{|l|c|c|}
\hline & $\begin{array}{c}\mathbf{2 0 0 7} \\
\text { RANK }\end{array}$ & $\begin{array}{c}\mathbf{2 0 1 4} \\
\text { RANK }\end{array}$ \\
\hline $\begin{array}{l}\text { Overpriced products } \\
\text { Previsoke cijene proizvoda }\end{array}$ & 1 & 1 \\
\hline Inconsistent supply / Nepouzdana opskrba & 2 & 2 \\
\hline Inconsistent quantities / Nestalne količine & 3 & \\
\hline Inadequate service / Neadekvatna usluga & 4 & \\
\hline Late delivery /Kasna isporuka & 5 & 3 \\
\hline Product quality / Kvaliteta proizvoda & & 5 \\
\hline Contract fulfillment / Ispunjenje ugovora & & 4 \\
\hline
\end{tabular}

premium for certified wood raw materials increasing to $89 \%$ of respondents in 2014.

Respondents were asked about the problems or challenges they face when purchasing certified wood product materials. Table 2 shows that Overpriced Products and Inconsistent Supply have been ranked \#1 or \#2 for the three time periods. Supplier Service, Delivery, and Contracts as well as Product Quality do not appear to be significant issues.

\subsection{Selling certified products}

3.5. Prodaja certificiranih proizvoda

On the sales side of the supply chain, the percent of total company sales, on average, attributed to certified products increased marginally from $21 \%$ in 2007 to $22 \%$ in 2014 . The volume of certified products sold by respondents generally decreased over the previous five years for each study period. In $2007,4 \%$ of respondents said sales had decreased in the previous 5 years, while in 2014, $18 \%$ of respondents said sales decreased. The percent of respondents saying that certified wood products sales increased in the previous 5 years declined from $56 \%$ of respondents in 2007 to 40 $\%$ in 2014 . The percent of respondents that saw no change was $40 \%$ and $42 \%$ of respondents in 2007 and 2014, respectively.

The customer base for certified wood products remained fairly consistent between time periods with Institutional Customers, State Governments, Custom Woodworking Jobs, and Municipalities ranked highest (Figure 6). With regard to the geographic market profile, the only major change (significant at $\alpha=0.01$ using a 2-tailed t-test) was the decrease in the percent of sales to In-State markets, which declined from $27 \%$ to $11 \%$ of respondents (Figure 7). Local Markets and those in Other States increased, while Export markets remained the same at $8 \%$ of respondent markets.

In $2007,61 \%$ of respondents received a premium for certified wood products relative to the noncertified alternative. In 2014, this had dropped to 42 $\%$ of respondents receiving such a premium. When asked if their company incurred any additional costs 
...... Vlosky, Tasdemir, Gazo, Cassens: A Mid-Recession and Post-Recession Comparison...

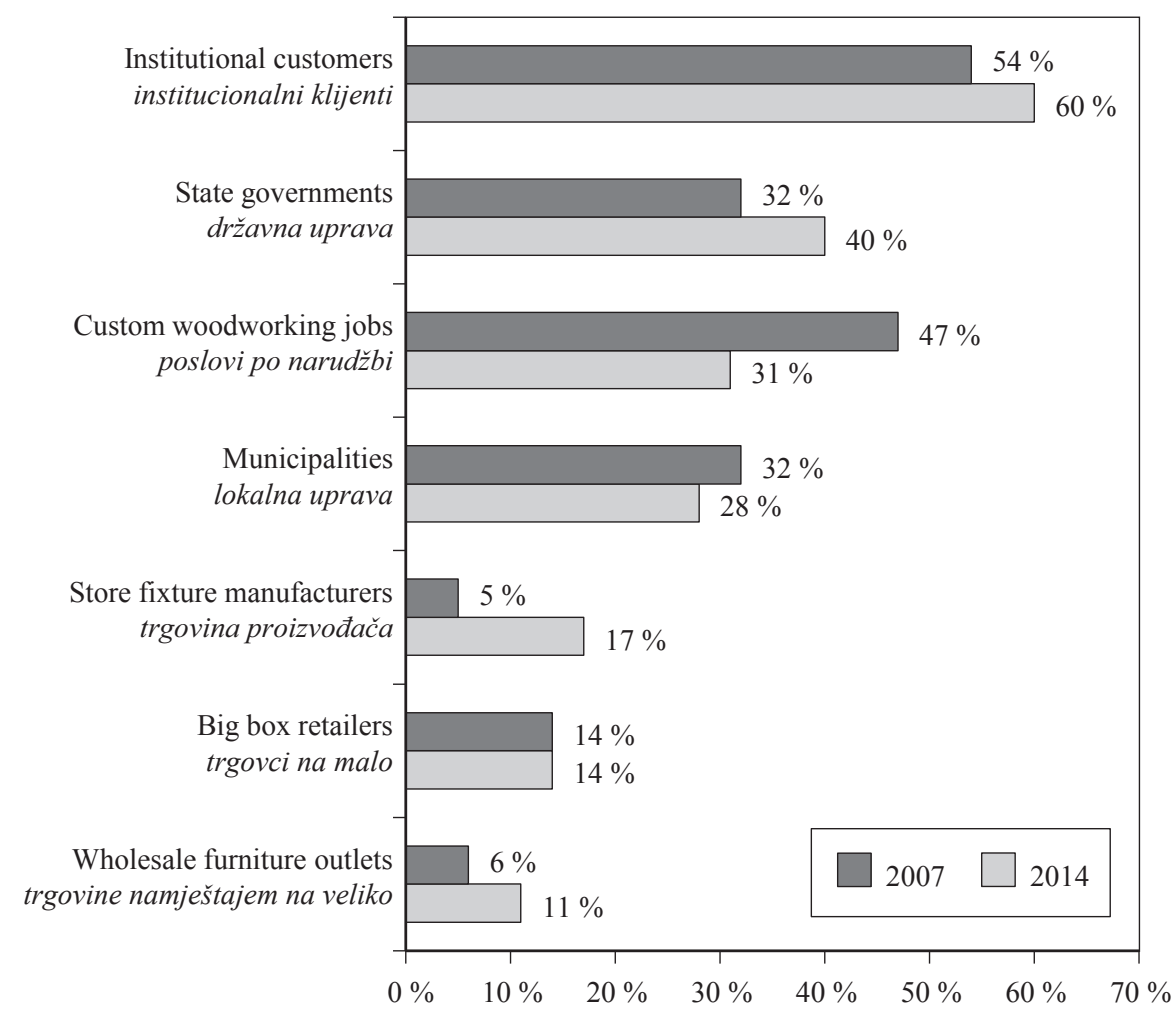

Figure 6 Customers for certified wood products (\% of respondents) (multiple responses possible) (2007: $n=193 ; 2014: n=99)$ Slika 6. Kupci certificiranih drvnih proizvoda (postotak ispitanika; mogući su višestruki odgovori) $(2007 .: n=193 ; 2014 .: n=99)$

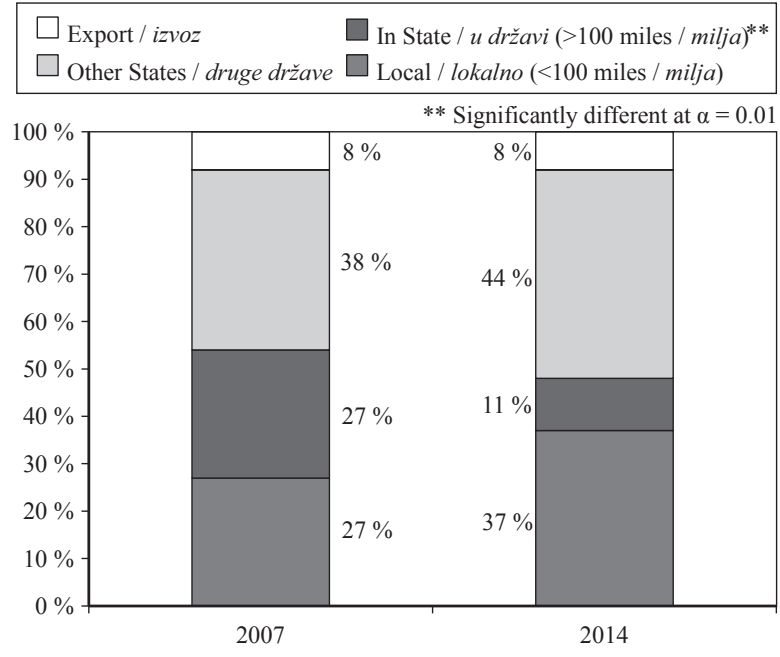

Figure 7 Geographic locations of customers for certified wood products (percent of respondents)

(multiple responses possible) $(2007: n=130 ; 2014: n=99)$

Slika 7. Zemljopisne lokacije kupaca certificiranih drvnih proizvoda (postotak ispitanika; mogući su višestruki odgovori) (2007.: $n=130 ; 2014 .: n=99)$

to provide certified products to their customers, the percent of respondents saying this was the case increased from $77 \%$ of respondents in 2007 to $90 \%$ of respondents in 2014.

The final questions asked respondents to look ahead into the future with regard to their plans to sell certified wood products. Overwhelmingly, respondents in both years said they planned to continue selling certified products $(97 \%$ and $98 \%$ of respondents in 2007 and 2014, respectively). However, in 2007, $84 \%$ of respondents saw their sales volume of certified products increasing in the future, while in 2014, only $45 \%$ of respondents felt this to be the case; in 2007, $14 \%$ of respondents saw sales as remaining the same in the future, while $43 \%$ in 2014 believed this to be true. This suggests a slowing in the rate of growth for certified wood products for existing companies.

\section{CONCLUSION 4. ZAKLJUČAK}

The U.S. forest products industry has not fully recovered from the recession of 2007-2008. In this comparative temporal study, we found that certification understanding, awareness and participation increased between this recessionary period and 2014. In examining possible effects of the recession, results show that the primary motivational factors for certification participation shifted from market driven to customer driven. In the quest to find new markets, expand existing markets, or simply remain in business, the provision of certified "green" products may have been part of respondent competitive strategies. This strategy seems to have created pressure on margins for the sale of certified products. For example, the percent of respondents receiving premiums for certified wood products declined by $31 \%$, while the percent of respondents paying a premium for certified raw materials increased by $20 \%$. Certification has matured and expanded since its inception. Results suggest that certification continues to be an important part of doing business for the valueadded wood products sector in the U.S. with almost all 
respondents in both studies having plans to continue selling certified wood products.

\section{REFERENCES}

5. LITERATURA

1. Berg, R. S.; Lovaglio, R., 2012: Forest certification - Opportunity and Challenge for the Wood Pellet Industry (April), 1-5.

2. Bowers, T.; Ganguly, I.; Eastin, I.; Bowers, T., 2014: Ecolabeled wood products in the U. S. residential construction industry: Architects' awareness and usage of certified wood and green building programs, 90: 605-613.

3. Cashore, B. W.; Auld, G.; Newsom, D., 2004: Governing through markets: Forest Certification and the Emergence of Non-State Authority. New Haven: Yale University Press. Retrieved from http://www.iddri.org/Activites/ Conferences-internationales/071122_atelierforet_pstation_Ben_Cashore.pdf.

4. Espinoza, O.; Buehlmann, U.; Dockry, M., 2013: Status of Forest Certification. International Scientific Conference on Hardwood Processing, ISCHP 2013, 298-305.

5. Espinoza, O.; Buehlmann, U.; Smith, B., 2012: Forest certification and green building standards: Overview and use in the U.S. hardwood industry. Journal of Cleaner Production, 33: 30-41. http://doi.org/10.1016/j.jclepro.2012.05.004.

6. Fernholz, K.; Bowyer J. L.; Bratkovich, S.; Frank, M.; Groot, H.; Howe, J.; Pepke, E., 2015: Forest Certification Update: Changes to the SFI and FSC Standards in 2015. Dovetail Partners Inc. (March), 1-11.

7. Fernholz, K.; Bowyer, J. L.; Frank, M.; Howe, J., 2012: Chain-of-Custody Certification \& Group Chain-of-Custody Certification. Dovetail Partners Inc., 1-5.

8. Fernholz, K.; Howe, J.; Bratkovich, S.; Bowyer, J., 2010: Forest Certification : A Status Report. Dovetail Partners Inc.

9. Maletz, O.; Tysiachniouk, M., 2009: The effect of expertise on the quality of forest standards implementation: The case of FSC forest certification in Russia. Forest Policy and Economics, 11(5-6): 422-428. http://doi.org/10.1016/j.forpol.2009.03.002.
10. Marx, A.; Cuypers, D., 2010: Forest certification as a global environmental governance tool: What is the macro-effectiveness of the Forest Stewardship Council? Regulation \& Governance, 4 (4): 408-434. http://doi.org/10.1111/j.1748-5991.2010.01088.x.

11. Moore, S. E.; Cubbage, F.; Eicheldinger, C., 2012: Certification in North America. Journal of Forestry, 79-88.

12. Vlosky, R.; Gazo, R.; Cassens, D., 2003: Certification involvement by selected United States value-added solid wood products sectors. Wood and Fiber Science, 35 (4): 560-569. Retrieved from $<$ Goto ISI $>$ ://000186529500008.

13. Vlosky, R.; Gazo, R.; Cassens, D.; Perera, P. 2009: Changes in value-added wood product manufacturer perceptions about certification in the United States from 2002 to 2008. Drvna industrija, 60 (2): 89-94. Retrieved from $<$ Go to ISI $>$ ://000274249500003.

14. ***FSC. 2016: Facts \& Figures (January). Retrieved from http://www.stnet.ch/fr/st-fr/portrait-st/facts-figures-1-1.html.

15. ***PEFC. 2014: PEFC Global Statistics: Members; Endorsed Systems; Distribution of Certificates (December), $1-15$.

16. ***PEFC. 2015: PEFC Global Statistics: Members; Endorsed Systems; Distribution of Certificates (November), $1-15$.

17. ***SFI. 2015a: 1995-2015: Celebrating 20 years of leadership and growth 2015.

18. ***SFI. 2015b: Future Forests-2014 Progress Report (November 2014).

\section{Corresponding address:}

Professor RICHARD VLOSKY, Ph. D., FIWSc

Louisiana Forest Products Development Center Louisiana State University Agricultural Center Baton Rouge, Louisiana 70803 USA

e-mail: vlosky@1su.edu 